\title{
Coastal infrastructure vulnerability: an integrated assessment model
}

\author{
Komali Kantamaneni ${ }^{1,2}$
}

Received: 12 February 2016/ Accepted: 2 June 2016/Published online: 12 July 2016

(C) The Author(s) 2016. This article is published with open access at Springerlink.com

\begin{abstract}
The significance of coastal regions to the infrastructure and the need to protect such assets are crucial to the economy of countries. Therefore, there is a real need to enhance the understanding of coastal infrastructure susceptibility as well as to develop methodologies to estimate vulnerability. A review of the literature regarding coastal vulnerability reveals that the focus has been on geomorphological and physical parameters but not infrastructure and the associated fiscal factors. In order to address this knowledge gap, an innovative model is developed, i.e., the Coastal Infrastructure Vulnerability Index (CIVI). Then the model is applied to the case of the Aberystwyth coast demonstrating how the model estimates the vulnerability of the coastal infrastructure (comprising population, commercial and residential properties). Subsequently, the CIVI scores were used to rank coastal sections into five classes, ranging from extremely low to extremely high, based on the relative magnitude of the vulnerability. The rankings for each parameter were combined, and then an index value was calculated. Results revealed that Aberystwyth contains more than $£ 40$ billion of coastal infrastructure vulnerability and more than 10,000 inhabitants are at the high coastal risk posed by flooding, erosion, storm surges, and strong winds.
\end{abstract}

Keywords Integrated model · Coastal infrastructure vulnerability index (CIVI) · Aberystwyth · Costs

Komali Kantamaneni

Komali.kantamaneni@uwtsd.ac.uk

1 Faculty of Architecture, Computing and Engineering, University of Wales, Trinity Saint David, Mount Pleasant, Swansea SA1 6ED, UK

2 School of Maritime and Engineering, Southampton Solent University, E Park Terrace, Southampton, Hampshire SO14 0YN, UK 


\section{Introduction}

Several coastal regions across the world are endangered to both natural and anthropogenic hazards, which are expected to increase in the near future (Nicholls et al. 2007; Kron 2008; Weisse et al. 2012). The construction of a variety of infrastructures such as properties (commercial and residential), roads, ports, and breakwaters completely dominates the natural habitats and leads to further rapid coastal damage. Humans have changed coastal regions by introducing artificial constructions in $2580 \mathrm{BCE}$ on the Red Sea shores in the Egypt (Tallet and Marouard 2014), and these structures affect geomorphology and coastal systems (Bulleri and Chapman 2010) in a negative way; however, this impact severity depends on the particular geographical area. Climate change induced elements such as sealevel rise, coastal flooding, erosion, and storm surge are the main reasons for coastal infrastructure damage as well as vulnerability (Dolan and Walker 2006; Phillips and Jones 2006; Bosello and De Cian 2014). Increased weather events also affect the socio-economic circumstances of coastal regions significantly (Hinkel et al. 2010). Therefore, coastal infrastructure vulnerability needs assessment to a greater degree to ameliorate existing problems and to prevent further decline.

\subsection{Coastal vulnerability appraisal methods}

Since three decades several works have been made to establish strategies and procedures for evaluating coastal vulnerability to climate change and other related aspects, accompanied with economics (Cutter et al. 2003; Lewsey et al. 2004; Vincent 2004; Rygel et al. 2006; Phillips and Jones 2006; Hinkel et al. 2009; Torresan et al. 2012; Addo 2013; Tang et al. 2013; Wolters and Kuenzer 2015; Denner et al. 2015; Wu et al. 2016). A summary of several methodologies established and applied globally is provided here. The four primary methods (Ramieri et al. 2011) to evaluate coastal vulnerability to climate change are as follows:

1. Index-based methodology

2. Indicator-based methodology

3. GIS (geographical information systems) based decision support systems

4. Dynamic computer models

\subsubsection{Index-based methodology}

Index-based methods evaluate coastal vulnerability by a single magnitude and are normally unit less. This method measures by the quantitative or semi-quantitative assessment as well as an amalgamation of diverse variables. These methods are not directly transparent since the final index does not allow for the understanding of the expectations and combinations that led to its measurement. The CVI outcomes can be shown on vulnerability maps at various scales to identify regions where the elements that add to coastal changes make greatest contributions to coastline retreat (Harvey and Woodroffe 2008; Pendleton et al. 2010). First coastal vulnerability index was developed by Gornitz (1990) followed by several researchers developing diverse CVI indices across the globe (McLaughlin and Cooper 2010; Palmer et al. 2011; Yin et al. 2012; Denner et al. 2015). 


\subsubsection{Indicator-based methodology}

An indicator-based index is a popular tool for measuring the intensity of exposure of communities to hazards and coastal vulnerability. The index comprises several indicators, which are interlinked with the specific formula. In recent decades, some researchers have established several vulnerability indicators within the socio-economic and ecological system context (King and MacGregor 2000; Brooks et al. 2005; Barnett et al. 2008; Torresan et al. 2008; Abson et al. 2012; Balica et al. 2012).

\subsubsection{GIS-based decision support systems (GIS-DSS)}

GIS-based methodologies are useful for evaluating the physical condition of a particular system and the development of risk maps. It is useful to acquire further information about the physical geography of particular region through computerisation to transmute vast databases into thematic maps. The GIS-DSS is two types; development of an information technology tool for the management of Southern European lagoons under the influence of river-basin runoff (DITTY-DSS) (Agnetis et al. 2006; Mocenni et al. 2009; Casini et al. 2015) and decision support system for coastal climate change impact assessment (DESYCO-DSS) (Santoro et al. 2013; Zanuttigh et al. 2014).

\subsubsection{Dynamic computer models}

Dynamic computer simulations are useful for analysing and mapping susceptibility and risks of coastal systems (Cowell et al. 1995; Brown et al. 2006). Available methods for this procedure can be divided into two parts; sector models and integrated assessment models. Sector models focus on the examination of coastal vulnerability linked to a specific coastal system, and integrated assessment models appraise the coastal vulnerability systems to multiple climate change impacts (Mcleod et al. 2010).

\subsection{Common framework for evaluation of coastal vulnerability}

In 1990, IPCC published a standard methodology for assessing the vulnerability of coastal areas to sea-level rise; it contains seven systematic stages (seven indicators) (Table 1) that permit for the identification of population, natural and physical resources at risk and costs and possibility of potential responses to adverse impacts (Nicholls 1995).

Though several other methods have been developed for coastal vulnerability assessment, most of the researchers focused their interest on the index- and indicator-based methods. However, there is no standard evaluation method on town/city scale to estimate the current infrastructure vulnerability of the Aberystwyth at current scenarios. Therefore, this study developed an integrated CIVI and subsequently analysed the infrastructure vulnerability of the population, commercial and residential properties of Aberystwyth, UK.

\section{Description of study area}

Aberystwyth $\left(52^{\circ} 25^{\prime} \mathrm{N} 4^{\circ} 05^{\prime} \mathrm{W}\right)$ is a small sea-side (Irish Sea) town in the county of Ceredigion in the Wales, UK (Aberystwyth Guide 2014) (Fig. 1), located towards the centre of the falcate of Cardigan Bay and also positioned between three hills. Aberystwyth 
Table 1 Indicators of the Coastal vulnerability-IPCC common approach (Gilbert and Vellinga 1990)

\begin{tabular}{|c|c|}
\hline Indicator & Explanation \\
\hline $\begin{array}{l}\text { Affected } \\
\text { Population }\end{array}$ & Number of people living in the hazard region affected by sea-level rise \\
\hline Population at risk & The average annual number of people inundated by storm surge \\
\hline $\begin{array}{l}\text { Investment value at } \\
\text { loss }\end{array}$ & Current market value of infrastructure which could be lost due to sea-level rise \\
\hline Land at loss & Size of land that would be lost due to rise of sea-level rise \\
\hline Wetland at loss & Size of area of wetland that would be lost due to sea-level rise \\
\hline Adaptation costs & Adaptation costs to sea-level rise, with an overwhelming importance on defence \\
\hline Population at risk & $\begin{array}{l}\text { The average number of people flooded by storm surge per year, supposing the cost of } \\
\text { adaptation to be in residence }\end{array}$ \\
\hline
\end{tabular}

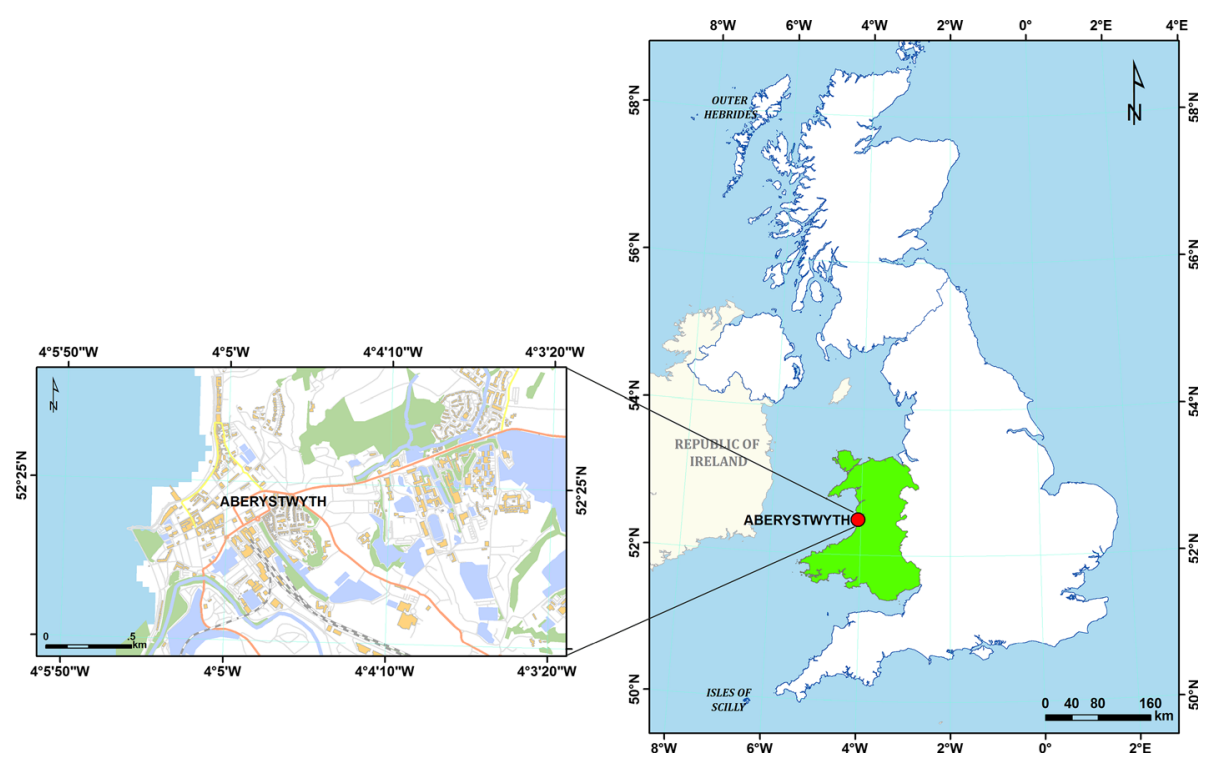

Fig. 1 Map of the study area

is the main touristic spot and administrative region of the west coast of Wales; though it has a small coastline ( $>2 \mathrm{~km}$ ) (Aberystwyth Guide 2014), it has a high socio-economic value because the town's economy is based mainly on tourism, education, and retail sectors.

\subsection{Coastal infrastructure damage}

Frequent storm strikes in Aberystwyth are not unusual phenomena. Starting several decades ago, repeated storms ravaged this region and damaged several £million to £billion worth of infrastructure (Fig. 2a-d as evidenced in 1927, 2008, 2013 and 2014 (major events). In particular, the 2014 massive tides ( $>20$ feet) damaged $>2 \mathrm{~km}$ of railway track 

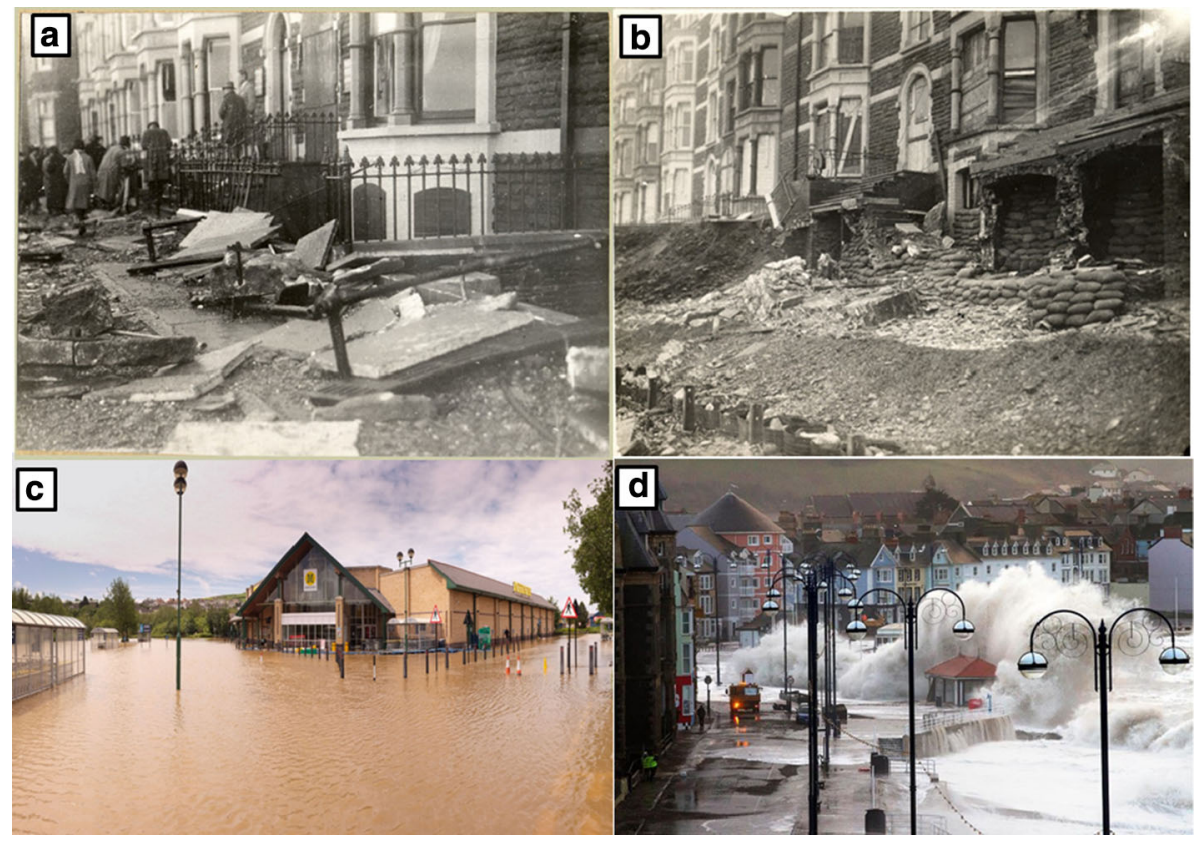

Fig. 2 Decadal Infrastructure Damage in Aberystwyth. a Residential property damage in 1927 (British Geological Survey 2014), b residential property damage in 1938 (British Geological Survey 2014), c commercial property damage in 2012 (Morris 2012), d commercial and residential property damage in 2014 (The Times 2014)

between Aberystwyth and Machynlleth severely, and nearly 2 weeks were needed for repairs. In addition, the widespread destruction of the seawall and walking path and the flooding of more than ten houses occurred (Welsh Government 2014). Future climatic conditions and levels of damage due to various coastal hazards (Table 2) will worsen the situation if strict adaptation and coastal defence procedures are not implemented in the near future (Slingo et al. 2014).

\section{Data}

Population, commercial and residential properties data were obtained from ONS (Office for National Statistics), local and sub-local Councils of Wales and Aberystwyth; fiscal data of commercial and residential properties obtained from HM Revenue and Customs (HMRC) offices of Wales and the Agricultural Mortgage Corporation (AMC). Along with the information as mentioned above, this study also utilised the data obtained by multiple observations of the coastal site of the Aberystwyth over 3 years (2012-2015) period. Parameter's statistics of each coastal cell (at $0.5 \mathrm{~km}$ resolution) was determined by using orthophotographs of Ordnance Survey, Welsh Assembly Government-Aerial Photographs and Google Earth maps. However, current study only used the data of rateable properties and did not take into consideration some heritage properties such as church and museums or massive structures like bridges and other constructions. While SPSS (statistical package for social sciences) (21st version) was used for analysis and exploration of 
Table 2 Coastal hazards of the Aberystwyth (Adopted from Ramieri et al. 2011)

\begin{tabular}{lll}
\hline $\begin{array}{l}\text { Principal } \\
\text { Marine regions }\end{array}$ & Coastal hazards & Vulnerability/impacts \\
\hline Celtic Sea & $\begin{array}{l}\text { Coastal flooding } \\
\text { Various storm events } \\
\text { Coastal erosion }\end{array}$ & $\begin{array}{l}\text { Infrastructure damage } \\
\text { Community loss }\end{array}$ \\
& Storm surge & Land degradation \\
& High waves, tides and winds & Damage to the coastline \\
& Coastal flooding & Damage to infrastructure \\
Irish Sea & Various storm events & Infrastructure damage \\
& Coastal erosion & Community loss \\
& Storm surge & Land degradation \\
& High waves & Damage to infrastructure \\
& & Damage to coastal wall and infrastructure
\end{tabular}

CIVI values and furtherer construction of CIVI. ArcGIS (10.3 version) and Welsh Assembly Government Arial and Google (Open Street) maps were used in the development of coastal vulnerability maps in various scales.

\section{Methodology}

\subsection{Development of an integrated model}

There is a real need to evaluate and compare the intensity of vulnerability of different sites, zones, and nations across the globe. The familiarity of coastal vulnerability will allow the researchers, policy, as well as decision makers to predict and perform on the adverse scenarios of existing and upcoming vicissitudes ensuing from global and regional sea-level rise and other impacts of climate change. A generalised and simple framework is required to illuminate explicit communication regarding coastal vulnerability and expressive comparison among susceptibility appraisals. Several kinds of technical, natural and social methods have already been employed (mentioned in the introduction section), but the process of applying the framework regionally and globally (from a fiscal perspective) is still in the embryonic stage. A definite procedure is then required to categorise the vulnerability of the coastal infrastructure; accordingly, a novel integrated model has been developed for the evaluation of coastal infrastructure vulnerability of the Aberystwyth coast, i.e., CIVI.

Two coastal vulnerability index (CVI) approaches were adopted for this study, based on an adaptation of the work of Balica et al. (2012) and Palmer et al. (2011). Accordingly, an integrated model (Fig. 3) was established to evaluate the vulnerability of the Aberystwyth coast by amalgamating indicator and index-based methods. The fiscal parameters were selected using the indicator-based method of Balica et al. (2012), and the concept of development of CIVI was taken from the index-based approach of Palmer et al. (2011). The fiscal values threshold for parameters was inspired by Aberystwyth fiscal consequences.

\subsection{Fiscal parameters selection}

Current study scrutinised various events in relation to a coastal vulnerability in the UK, such as population, commercial and residential properties, storm conditions, rainfall trends, 


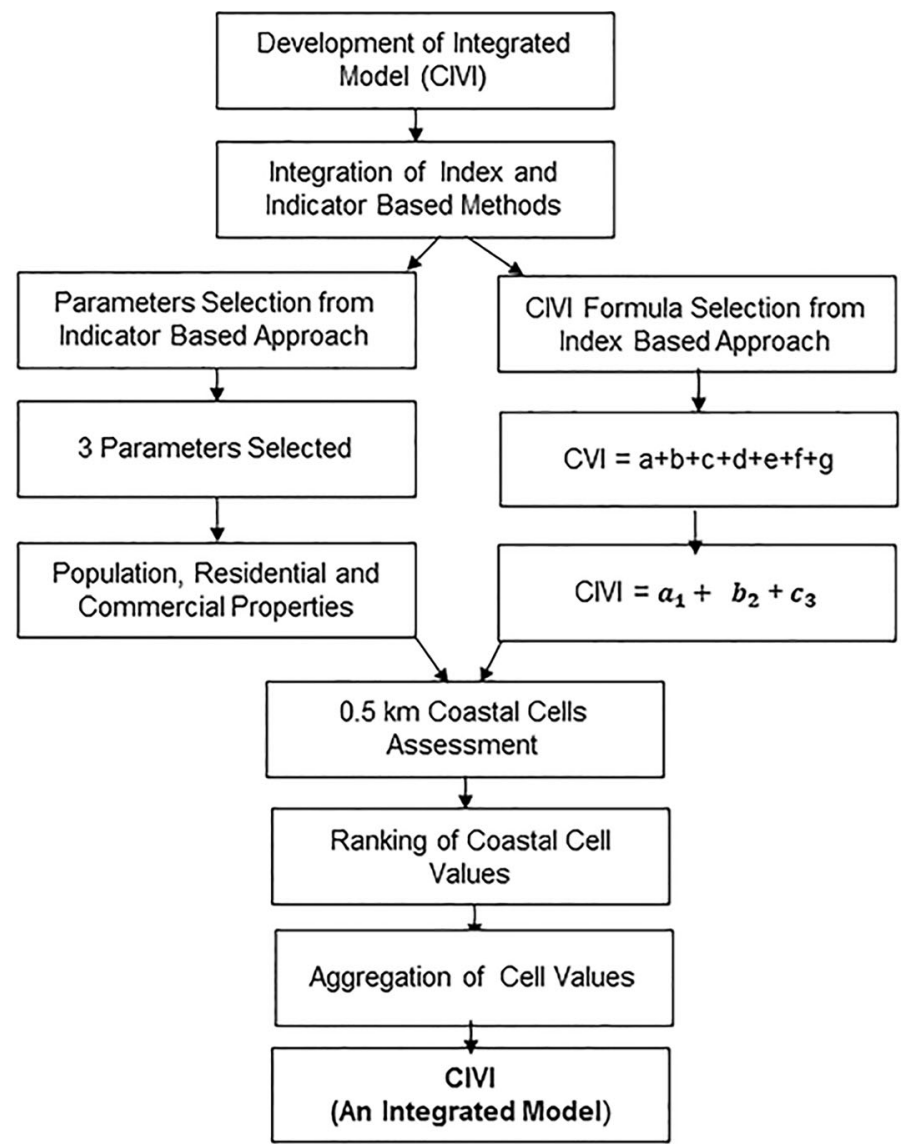

Fig. 3 Flow chart of development of integrated model

coastal erosion, etc. Based on the analysis of various conditions, which are presented in Table 3, twelve parameters were selected, taking into account the UK coastal regions and their susceptibility and exposure to the coastal vulnerability events.

\subsubsection{Reduction of parameters}

Reduction of parameters for an evaluation of fiscal coastal vulnerability at city or town scale is necessary. A large number of parameters (12) does not offer factual results in this particular scenario, so to simplify the methodological process, they are reduced and restricted to 3 , based on the potentiality of the parameters (Table 4). Parameter reduction is not a new procedure in coastal vulnerability assessment studies, and several researchers have already implemented this technique successfully. Balica et al. (2012) initially considered 71 indicators and then reduced their number to 12, and the Canadian Council of Ministries of Environment (2003) selected nearly 100 indicators, which were reduced to 12 as well. 
Table 3 Parameters selection procedure

\begin{tabular}{|c|c|c|}
\hline Number & Parameter & Selection process and reason \\
\hline 1 & $\begin{array}{l}\text { Population in coastal } \\
\text { vulnerability zones }\end{array}$ & $\begin{array}{l}\text { More than } 50 \% \text { of population is living near the coastline (Small } \\
\text { and Nicholls 2003) }\end{array}$ \\
\hline 2 & $\begin{array}{l}\text { Infrastructure (properties, } \\
\text { roads, etc.) }\end{array}$ & $\begin{array}{l}\text { Nearly } 6 \text { million properties (one in six) are at risk of coastal } \\
\text { flooding and erosion (Ramsbottom et al. 2012) }\end{array}$ \\
\hline 3 & Land use & $\begin{array}{l}\text { Around } 60 \% \text { of the best agricultural land is } 5 \mathrm{~m} \text { or less above sea } \\
\text { level (Zsamboky et al. 2011) }\end{array}$ \\
\hline 4 & Rainfall & $\begin{array}{l}\text { Heavy rainfall trends across the country in recent decades (Osborn } \\
\text { and Hulme 2002; Maraun et al. 2008) }\end{array}$ \\
\hline 5 & Flood/storm impact & $\begin{array}{l}\text { Increased severity of flood/storm impact in recent periods } \\
\quad \text { (Reynard et al. 2001; Woodworth et al. 2007; Stevens et al. 2014) }\end{array}$ \\
\hline 6 & Fiscal value of the place & $\begin{array}{l}\text { The economic value of the area plays a vital role in fiscal studies, } \\
\text { as well as disaster management studies (Swarbrooke 1999; Haigh } \\
\text { and Amaratunga 2010) }\end{array}$ \\
\hline 7 & Coastal erosion & $\begin{array}{l}\text { High coastal erosion at some regions of the UK (Phillips and Jones } \\
\text { 2006; Kantamaneni and Phillips 2016) }\end{array}$ \\
\hline 8 & $\begin{array}{l}\text { High growth of population } \\
\text { alongside coasts }\end{array}$ & $\begin{array}{l}\text { High growth of population expected alongside coasts (Small and } \\
\text { Nicholls 2003). }\end{array}$ \\
\hline 9 & Drainage system & $\begin{array}{l}\text { A poor drainage system causes severe problems particularly when } \\
\text { flooding strikes (Coulthard and Frostick 2010; Butler and Davies } \\
\text { 2004) }\end{array}$ \\
\hline 10 & Warning system & $\begin{array}{l}\text { The robustness of the UK's warning system for natural disasters, } \\
\text { e.g. no warning system during tornado strikes (Kantamaneni } \\
\text { et al. 2015) }\end{array}$ \\
\hline 11 & Marine Industry Growth & $\begin{array}{l}\text { Maritime industries and the service sector annually contributes } \\
>£ 17 \text { billion to the UK economy and it will be } £ 25 \text { billion by } \\
2020 \text { (Marine Industries Leadership Council 2011) }\end{array}$ \\
\hline 12 & Politics and Policies & $\begin{array}{l}\text { Changing the political situation also plays a vital role in the } \\
\text { assessment of coastal vulnerability (White and Howe 2002; Patt } \\
\text { et al. 2009) }\end{array}$ \\
\hline
\end{tabular}

Table 4 Fiscal (coastal infrastructure vulnerability) parameters

\begin{tabular}{llll}
\hline No. & Parameter & Designated symbol for CIVI & Measurable units (f) \\
\hline 1 & Population & $a 1$ & Million-billion (economic) \\
2 & Residential property & $b 2$ & Million-billion (economic) \\
3 & Commercial property & $c 3$ & Million-billion (economic) \\
\hline
\end{tabular}

\subsubsection{Parameters description}

The population is widely accepted imperative parameter in both physical and socio-economic sections of coastal research, and it also considers as one of the vital infrastructures (Simone 2004). Current study measures the population in monetary terms and sets a cost to the human life based on US-2011-Environment Protection Agency estimations, i.e., $£ 6.9$ million (adjusted for 2015 inflation £rates) (Appelbaum 2011). However, Aberystwyth population has diverse age groups and communities with different economic status; 
therefore, this study offers on average $£ 4 \mathrm{~m}$ to the life of the UK (Aberystwyth) people at current scenarios. ${ }^{1}$

Residential and commercial properties are also important parameters in the coastal vulnerability studies. Using these structures as parameters in coastal vulnerability studies is not new; several researchers used in their studies to evaluate vulnerability in both physical and socio-economic studies throughout the world (Klein et al. 2003; Jacob et al. 2007; Kubal et al. 2009; Thatcher et al. 2013; Arkema et al. 2013; Wu et al. 2016; Mazumdar and Paul 2016). The Economic threshold was offered by identifying a number of properties in $0.5 \mathrm{~km}$ cells and then estimated the commercial value of those properties and then provided the range of values from extremely low to extremely high.

\subsection{Technical description and calculation of CIVI}

A certain length of transect line was drawn on the Aberystwyth coastline, and then a $0.5 \mathrm{~km}$ square measurement was placed on the transect line from the coast point to outside of coast, i.e., towards the civilisation/communities (Fig. 4) to appraise coastal infrastructure vulnerability within the economic perspective, while, as shown in Fig. 4, second and third cells are overlapped. Therefore, these overlapped properties did not take into consideration for an evaluation. However, uncovered properties which are located in-between the cells of first and second as well as third and fourth are taken into account for an assessment. This consideration helps to attain factual fiscal figures.

Besides that, fiscal parameter ranking was (Table 5) used to measure the coastal vulnerability and subsequently each cell was assigned a CIVI score and then all the cells of the parameters were calculated.

This study categorised the CIVI scores into five categories: extremely low (1), low (2), moderate (3), high (4) and extremely high (5). The scores of all cells of three parameters aggregated to rank the coastal infrastructure vulnerability. With rankings applied these values were then put into a simple equation (Eq. 1) to analyse CIVI score for each coastal section. Simple summation of individual rankings provided a total relative vulnerability score. The minimum possible score was 3 , and the maximum was 15 .

$\begin{array}{cr}\text { Relative CIVI }=a_{1}+b_{2}+c_{3} & 5(\max ) \\ a_{1} \text {-Population } & 5(\max ) \\ b_{2}-\text { Residential property } & 5(\max ) \\ c_{3}-\text { Commercial Property } & \\ & \\ \text { Maximum CIVI score } & 15 \\ \text { Minimum CIVI score } & 3\end{array}$

1 It is not possible to give same fiscal consequences to all age groups of population of Aberystwyth and, accordingly this study offer the costs on average $£ 4 \mathrm{~m}$ to the life of the human. 


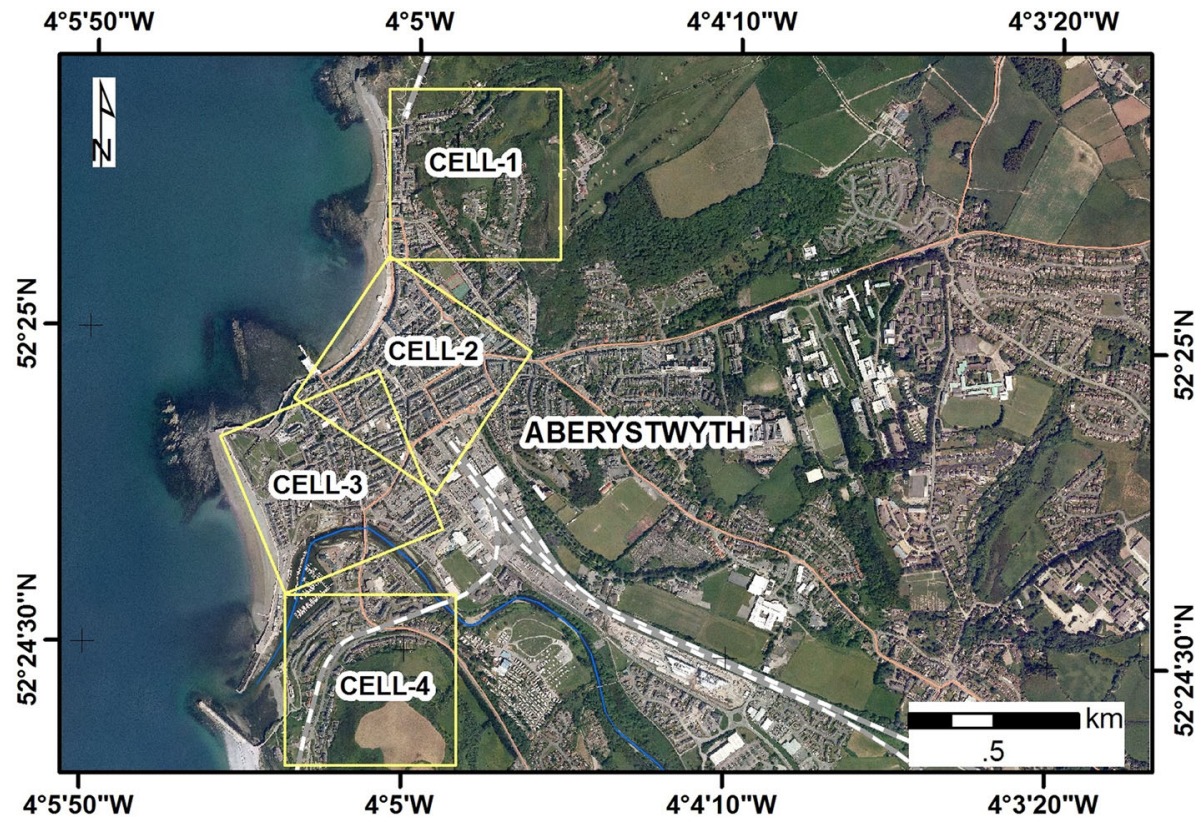

Fig. 4 Coastal cell $(0.5 \mathrm{~km})$ on transect line

Table 5 CIVI Parameter Ranking

\begin{tabular}{llllll}
\hline Fiscal & 1 & 2 & 3 & 4 & 5 \\
Parameter & $\begin{array}{l}\text { Extremely Low } \\
£\end{array}$ & $\begin{array}{l}\text { Low } \\
£\end{array}$ & $\begin{array}{l}\text { Moderate } \\
£\end{array}$ & $\begin{array}{l}\text { High } \\
£\end{array}$ & $\begin{array}{l}\text { Extremely High } \\
£\end{array}$ \\
\hline Population & $<1 \mathrm{bn}$ & $1 \mathrm{bn}-6 \mathrm{bn}$ & $>6 \mathrm{bn}-12 \mathrm{bn}$ & $>12 \mathrm{bn}-20 \mathrm{bn}$ & $>20 \mathrm{bn}-28 \mathrm{bn}$ \\
Residential property & $<30 \mathrm{~m}$ & $30 \mathrm{~m}-80 \mathrm{~m}$ & $>80 \mathrm{n}-30 \mathrm{~m}$ & $>130 \mathrm{~m}-180 \mathrm{~m}$ & $>180 \mathrm{~m}-1 \mathrm{bn}$ \\
Commercial property & $<2 \mathrm{~m}$ & $2 \mathrm{~m}-10 \mathrm{~m}$ & $>10 \mathrm{~m}-30 \mathrm{~m}$ & $>30 \mathrm{~m}-70 \mathrm{~m}$ & $>70-300 \mathrm{~m}$ \\
\hline
\end{tabular}

( $m$ million, $b n$ billion)

Coastal sections scoring within the mid-range (7-9) were ranked as moderate vulnerability, and coastal sections scoring in between 13 and 15 were categorised as an extremely high vulnerability. However, the ranking system as follows (Table 6);

\section{Results and discussion}

More than two km transect line was drawn on Aberystwyth coast and accordingly, four $0.5 \mathrm{~km}$ cells placed and then measured. Currently, this town has thousands of coastal population and very expensive properties (commercial and residential) (Table 7).

Moreover, Aberystwyth is critically vulnerable to wave attacks and high tides (Fig. 5). For several decades, it has been affected severely by a series of storms with high waves, tides, and storm surges, particularly in 2008, 2010, 2013, and 2014. Specifically, 2014 storm ravaged this region and caused an astonishing $>£ 1.5 \mathrm{~m}$ worth of damage to the 
Table 6 Vulnerability level ratings classified by total relative vulnerability score

\begin{tabular}{lc}
\hline Relative vulnerability score & Rating of vulnerability \\
\hline Extremely high vulnerability & $13-15$ \\
High vulnerability & $10-12$ \\
Moderate vulnerability & $7-9$ \\
Low vulnerability & $4-6$ \\
Extremely low vulnerability & $1-3$ \\
\hline
\end{tabular}

\begin{tabular}{ll}
\hline Infrastructure name & Number \\
\hline Commercial properties & 758 \\
Residential properties & 6591 \\
Population & 15,139 \\
\hline
\end{tabular}

Table 7 Infrastructure details of Aberystwyth
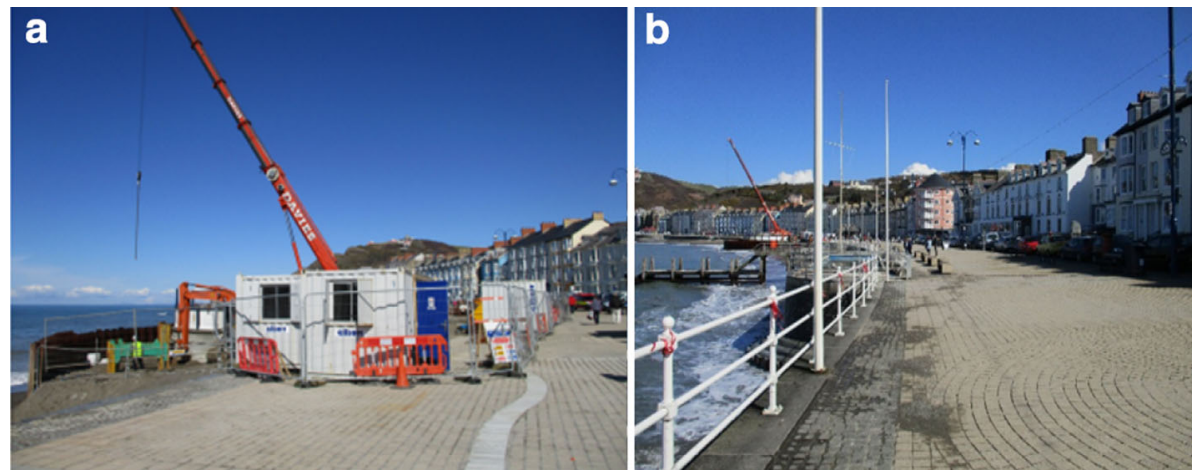

Fig. 5 a Construction of new coastal wall (during 2014 flood strike, coastal wall was severally damaged), b commercial and residential properties near the coastline in Aberystwyth (photographs were taken by author-2015)

infrastructure (Ceredigion County Council 2014). The tidal range in the area is always greater than on other sites, with the largest increase of waves coming from the south-west, which is also the direction of the most frequent storms.

Though Aberystwyth has a shorter coastline, it has a high coastal infrastructure vulnerability and comparatively uneven across the coast. Some coastal cells are extremely high, and some are high to moderate vulnerability. Extremely high CIVI scores were recorded at the second and third cells, high at the fourth cell, and moderate at the first cell (Fig. 6). Currently, Aberystwyth has $>40$ bn worth of CIV (Fig. 7) with 4613 residential properties, 530 commercial properties, and $>10,017$ people are at high coastal risk.

\section{Limitations}

Due to the lack of recent literature (most of the research information is more than 10 years old) on Aberystwyth coastal vulnerability in both physical and fiscal aspects, there is not much scope to compare with other similar existing studies, especially at regional and 


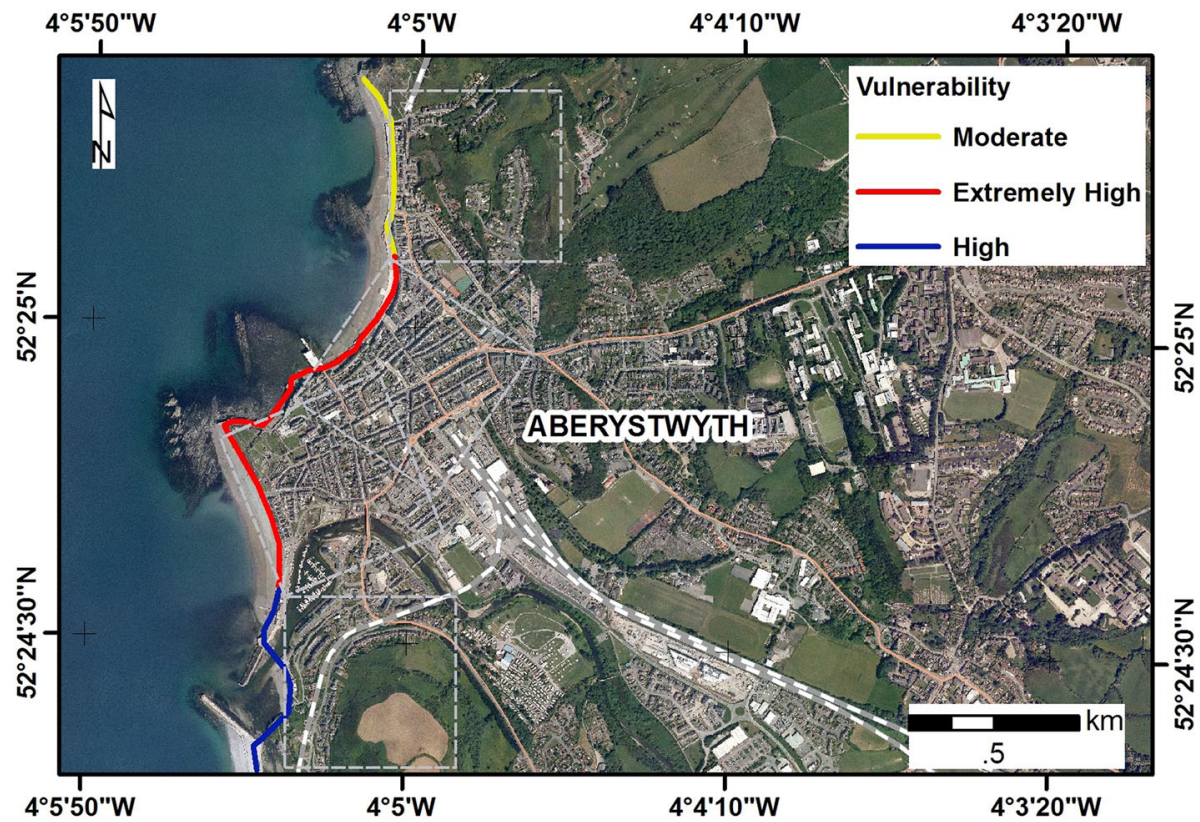

Fig. 6 Coastline vulnerability rates superimposed upon the aerial photograph

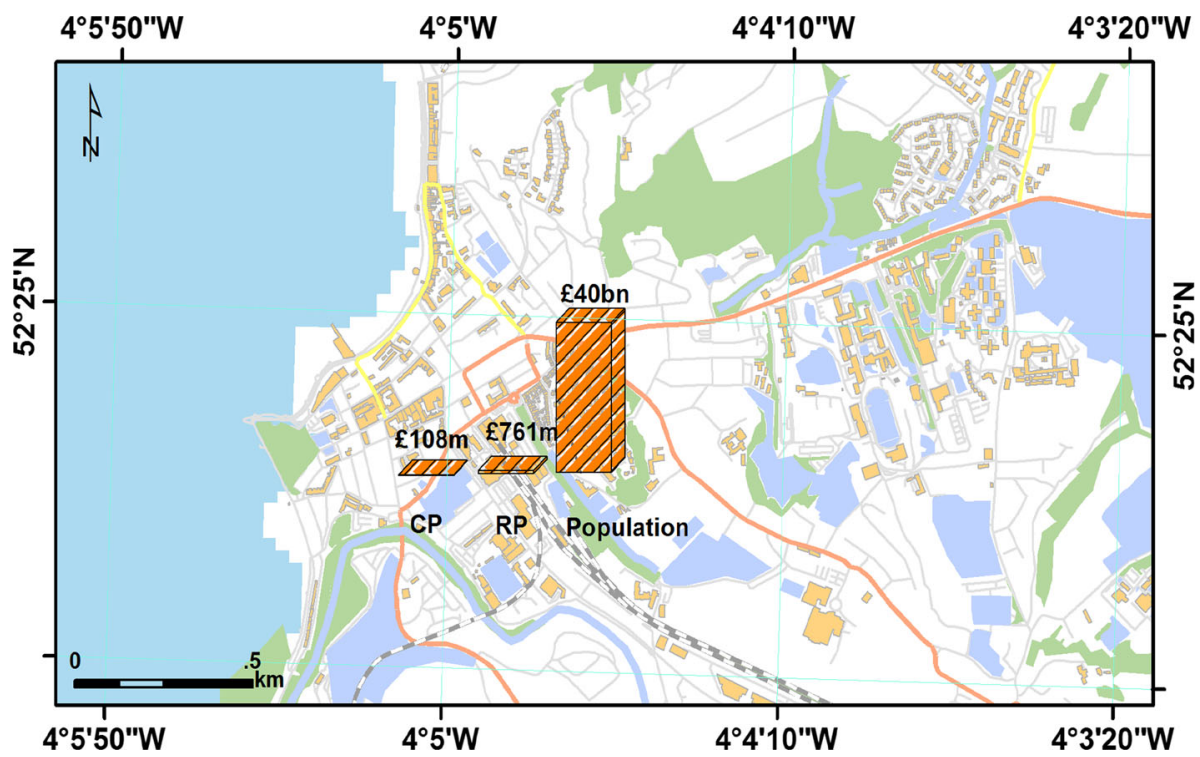

Fig. 7 Fiscal coastal vulnerability map of Aberystwyth (CP-commercial properties; RP-residential properties)

city/town scales. With these concerns in mind, the subsequent vital subjects in any effort of simplification of the findings would need to be certified carefully, such as GDP, local economy, and redevelopment procedures. 


\section{Conclusion}

This study revealed the coastal infrastructure vulnerability of the Aberystwyth by the establishment of a novel integrated model, i.e., CIVI. Fiscal parameters that considered the existing economic conditions of the population, commercial and residential properties were used to appraise the relative economic coastal infrastructure vulnerability. Results showed that Aberystwyth consists of $>£ 40$ billion worth of CIV. Efficient and factual results for CIVI computation are intensely reliant on the quality and varied type of data used, which influence the vulnerability of a particular coastal stretch. This is a statistical and objective approach to illustrate the intensity of coastal infrastructure vulnerability at Aberystwyth coast. This integrated method enables the production of statistics and quantification of different levels of vulnerability to fulfil standards substitute to regional, local and sub-local authorities in the nationalised policy for control of climate change related coastal hazards in North Wales, UK. This technique of assessing infrastructure vulnerability can purpose as a primary susceptibility appraisal from which a map of probable intensities of vulnerability can be generated to allow cost-benefit scrutinise. The use of an appraisal of coastal infrastructure vulnerability can also be employed to define fiscal viability of coastal defence and the distribution of compelled funding. This model will be very useful to coastal economists, engineers and planning managers for better planning to reduce the coastal vulnerability.

Acknowledgments I would like to thank Professor Mike Phillips, Dr. Rhian Jenkins (University of Wales Trinity Saint David, UK) and Professor Nagesh Kumar (Indian Institute of Science, Bengaluru, India) for much valuable discussion, who supported my work with vital insights from their vast experience. A particular acknowledgement is made to my work associates Dr. Talib Butt and Dr. Tony Thomas for their valuable comments on the conceptual framework. I wish to give special thanks for the comments of anonymous reviewers on an earlier version, which contributed significantly to the improvement of the manuscript. I am also very grateful to the staff of Aberystwyth Council for providing updated statistics of population, commercial and residential properties and to Welsh Assembly Government, Aerial Photographs Unit, Cardiff, Wales, for the aerial photographs used in the study.

\section{Compliance with ethical standards}

Conflict of interest This manuscript has not been previously published and is not under consideration in the same or substantially similar form in any other peer-reviewed media. To the best of my knowledge, no conflict of interest, financial or other, exists.

Open Access This article is distributed under the terms of the Creative Commons Attribution 4.0 International License (http://creativecommons.org/licenses/by/4.0/), which permits unrestricted use, distribution, and reproduction in any medium, provided you give appropriate credit to the original author(s) and the source, provide a link to the Creative Commons license, and indicate if changes were made.

\section{References}

Aberystwyth Guide (2014) Introduction. http://www.aberystwythguide.org.uk/aberpix.shtml. Accessed 13 Jan 2016

Abson DJ, Dougill AJ, Stringer LC (2012) Using principal component analysis for information-rich socioecological vulnerability mapping in Southern Africa. Appl Geogr 35:515-524

Addo KA (2013) Assessing coastal vulnerability index to climate change: the case of Accra-Ghana. J Coastal Res 2:1892

Agnetis A, et al (2006) Development of a decision support system for the management of Southern European lagoons Center for Complex Systems Studies University of Siena, Siena, Italy Disponível em. http://www.dittyproject.org/Article/WP8_DSS_structure_final.pdf 
Appelbaum B (2011) As US agencies put more value on a life, businesses fret. The New York Times, 16. http://www.nytimes.com/2011/02/17/business/economy/17regulation.html?_r=0. Accessed 10 Mar 2014

Arkema KK et al (2013) Coastal habitats shield people and property from sea-level rise and storms. Nat Climate Change 3:913-918

Balica S, Wright NG, van der Meulen F (2012) A flood vulnerability index for coastal cities and its use in assessing climate change impacts. Nat Hazards 64:73-105

Barnett J, Lambert S, Fry I (2008) The hazards of indicators: insights from the environmental vulnerability index. Ann As Am Geogr 98:102-119

Bosello F, De Cian E (2014) Climate change, sea level rise, and coastal disasters. A review of modeling practices. Energy Econ 46:593-605. doi:10.1016/j.eneco.2013.09.002

British Geological Survey (2014) BGS Geo-heritage-images from the collections http://britgeoheritage. blogspot.co.uk/2013/06/storm-damage-in-aberystwyth-october.html. Accessed 25 July 2015

Brooks N, Adger WN, Kelly PM (2005) The determinants of vulnerability and adaptive capacity at the national level and the implications for adaptation. Global Environ Change 15:151-163

Brown I, Jude S, Koukoulas S, Nicholls R, Dickson M, Walkden M (2006) Dynamic simulation and visualisation of coastal erosion. Comput Environ Urban Syst 30:840-860

Bulleri F, Chapman MG (2010) The introduction of coastal infrastructure as a driver of change in marine environments. J Appl Ecol 47:26-35

Butler D, Davies J (2004) Urban drainage. CRC Press, Boca Raton

Canadian Council of Ministries of the Environment (2003) Climate, nature, people: indicators of Canada's climate change. www.ccme.ca. Accessed 28 June 2013

Casini M, Mocenni C, Paoletti S, Pranzo M (2015) Decision support system development for integrated management of European coastal lagoons. Environ Model Softw 64:47-57

Ceredigion County Council (2014) 2014 storm damage and repair costs. http://www.ceredigion.gov.uk/ English/Your-Council/Pages/default.aspx. Accessed 22 June 2015

Coulthard T, Frostick L (2010) The Hull floods of 2007: implications for the governance and management of urban drainage systems. J Flood Risk Manag 3:223-231

Cowell P, Roy P, Jones R (1995) Simulation of large-scale coastal change using a morphological behaviour model. Mar Geol 126:45-61

Cutter SL, Boruff BJ, Shirley WL (2003) Social vulnerability to environmental hazards*. Soc Sci Q $84: 242-261$

Denner K, Phillips M, Jenkins R, Thomas T (2015) A coastal vulnerability and environmental risk assessment of Loughor Estuary, South Wales. Ocean Coast Manag 116:478-490

Dolan AH, Walker I (2006) Understanding vulnerability of coastal communities to climate change related risks. J Coastal Res 3:1316-1323

Gilbert J, Vellinga P (1990) Strategies for adaption to sea level rise. Report of the Coastal Zone Management Subgroup, Intergovernmental Panel on Climate Change World Meteorological Organization and UN Environmental Programme: the Netherlands

Gornitz V (1990) Vulnerability of the East Coast, USA to future sea level rise. J Coastal Res 9:201-237

Haigh R, Amaratunga D (2010) An integrative review of the built environment discipline's role in the development of society's resilience to disasters. Int J Disaster Resilience Built Environ 1:11-24

Harvey N, Woodroffe CD (2008) Australian approaches to coastal vulnerability assessment. Sustain Sci 3:67-87

Hinkel J, Klein RJ (2009) Integrating knowledge to assess coastal vulnerability to sea-level rise: the development of the DIVA tool. Global Environ Change 19:384-395

Hinkel J, Nicholls RJ, Vafeidis AT, Tol RS, Avagianou T (2010) Assessing risk of and adaptation to sealevel rise in the European Union: an application of DIVA. Mitig Adapt Strat Global Change 15:703-719

Jacob KH, Gornitz V, Rosenzweig C (2007) Vulnerability of the New York City metropolitan area to coastal hazards, including sea-level rise: inferences for urban coastal risk management and adaptation policies. Manag Coastal Vulnerability: Global Reg Local Elsevier Publ 141-158

Kantamaneni K, Phillips M (2016) Transformation of climate: will floods and coastal erosion crumble the UK economy? Int J Climate Ch Impacts Responses 8:45-59

Kantamaneni K, Phillips M, Jenkins R, Oakley J, Ibeabuchi KO (2015) Could the UK economy be impacted by an increase in Tornado occurrence?: a consequence of climate change in the 21 st century. Int $\mathbf{J}$ Climate Ch Impacts Responses 7:29-39

King D, MacGregor C (2000) Using social indicators to measure community vulnerability to natural hazards. Aust J Emerg Manag The 15:52 
Klein RJ, Nicholls RJ, Thomalla F (2003) Resilience to natural hazards: how useful is this concept? Global environmental change. Part B Environ Hazards 5:35-45

Kron W (2008) Coasts-The riskiest places on Earth. In: Proceedings of the 31st international conference on coastal engineering (ICCE), World Scientific. Hamburg, Germany, pp 3-21

Kubal C, Haase D, Meyer V, Scheuer S (2009) Integrated urban flood risk assessment-adapting a multicriteria approach to a city. Nat Hazards Earth Syst Sci 9:1881-1895

Lewsey C, Cid G, Kruse E (2004) Assessing climate change impacts on coastal infrastructure in the Eastern Caribbean. Mar Policy 28:393-409

Maraun D, Osborn T, Gillett N (2008) United Kingdom daily precipitation intensity: improved early data, error estimates and an update from 2000 to 2006. Int Climatol 28:833-842

Marine Industries Leadership Council (2011) A strategy for growth for the UK marine industries. https:// www.gov.uk/government/uploads/system/uploads/attachment_data/file/31813/11-1310-strategy-forgrowth-uk-marine-industries.pdf. Accessed 12 Aug 2014

Mazumdar J, Paul SK (2016) Socioeconomic and infrastructural vulnerability indices for cyclones in the eastern coastal states of India. Nat Hazards 1-23

McLaughlin S, Cooper JAG (2010) A multi-scale coastal vulnerability index: a tool for coastal managers. Environ Hazards 9:233-248

Mcleod E, Poulter B, Hinkel J, Reyes E, Salm R (2010) Sea-level rise impact models and environmental conservation: a review of models and their applications. Ocean Coast Manag 53:507-517

Mocenni C, Casini M, Paoletti S, Giordani G, Viaroli P, Comenges J-MZ (2009) A decision support system for the management of the Sacca di Goro (Italy). In: Marcomini A, Suter GW, Critto A (eds) Decision support systems for risk-based management of contaminated sites. Springer, pp 1-24

Morris K (2012) Summer 2012 Part 1: The Great Flood of June 9th 2012: off the scale. http://www. geologywales.co.uk/storms/summer12a.htm. Accessed 15 Mar 2014

Nicholls RJ, Leatherman SP, Dennis K, Volonte C (1995) Impacts and responses to sea-level rise: qualitative and quantitative assessments. J Coast Res 1:26-43

Nicholls RJ, Wong PP, Burkett VR, Codignotto JO, Hay JE, McLean RF, Ragoonaden S, Woodroffe CD (2007) Coastal systems and low-lying areas. In: Parry ML, Canziani OF, Palutikof JP, van der Linden PJ, Hanson CE (eds) Climate change 2007: impacts, adaptation and vulnerability. Contribution of working group II to the fourth assessment report of the intergovernmental panel on climate change. Cambridge University Press, Cambridge, pp 315-356

Osborn TJ, Hulme M (2002) Evidence for trends in heavy rainfall events over the UK. Philos Trans R Soc Lond A Math Phys Eng Sci 360:1313-1325

Palmer B, et al (2011) Preliminary coastal vulnerability assessment for KwaZulu-Natal, South Africa. J Coastal Res 1390

Patt AG, Schroter D, Vega-Leinert ACDL et al (2009) Vulnerability research and assessment to support adaptation and mitigation: common themes from the diversity of approaches. In: Patt AG, Schroter D, Klein RJT, Vega-Leinert ACDL (eds) Assessing vulnerability to global environmental change: making research useful for adaptation, decision making and policy. Earthscan, London

Pendleton EA, Thieler ER, Williams SJ (2010) Importance of coastal change variables in determining vulnerability to sea-and lake-level change. J Coastal Res 176-183

Phillips MR, Jones AL (2006) Erosion and tourism infrastructure in the coastal zone: problems, consequences and management. Tour Manag 27:517-524

Ramieri E et al (2011) Methods for assessing coastal vulnerability to climate change European environment agency, European topic centre on climate change impacts, vulnerability and adaptation. pp 1-91. https://www.researchgate.net/profile/Andrea_Barbanti/publication/301296277_Methods_for_assessing_ coastal_vulnerability_to_climate_change/links/5710bd7008ae68dc790a2421.pdf. Accessed 15 June 2014

Ramsbottom D, Sayers P, Panzeri M (2012) Climate change risk assessment for the floods and coastal erosion sector Defra project code GA0204 report to Defra, London, UK

Reynard NS, Prudhomme C, Crooks SM (2001) The flood characteristics of large UK rivers: potential effects of changing climate and land use. Climat Change 48:343-359

Rygel L, O'sullivan D, Yarnal B (2006) A method for constructing a social vulnerability index: an application to hurricane storm surges in a developed country. Mitig Adapt Strat Global Change 11:741-764

Santoro F, Tonino M, Torresan S, Critto A, Marcomini A (2013) Involve to improve: a participatory approach for a decision support system for coastal climate change impacts assessment. The North Adriatic case. Ocean Coast Manag 78:101-111

Simone AM (2004) People as infrastructure: intersecting fragments in Johannesburg Public culture 16:407-429 
Slingo J et al (2014) The recent storms and floods in the UK. UK Met. Office and Centre for Ecology and Hydrology. http://www.metoffice.gov.uk/research/news/2014/uk-storms-and-floods. Accessed 10 Mar 2015

Small C, Nicholls RJ (2003) A global analysis of human settlement in coastal zones. J Coast Res 584-599 Stevens AJ, Clarke D, Nicholls RJ (2014) Trends in reported flooding in the UK. Hydrol Sci J 61:1884-2013

Swarbrooke J (1999) Sustainable tourism management. CABI 1-61

Tallet P, Marouard G (2014) The harbor of Khufu on the Red Sea Coast at Wadi al-Jarf. Egypt Near East Archaeol (NEA) 77:4-14

Tang HS et al (2013) Vulnerability of population and transportation infrastructure at the east bank of Delaware Bay due to coastal flooding in sea-level rise conditions. Nat Hazards 69:141-163

Thatcher CA, Brock JC, Pendleton EA (2013) Economic vulnerability to sea-level rise along the northern US Gulf Coast. J Coast Res 63:234-243

The Times (2014) Flood warnings as more rain arrives. http://www.thetimes.co.uk/tto/weather/ article3965949.ece. Accessed 21 Mar 2015

Torresan S, Critto A, Dalla Valle M, Harvey N, Marcomini A (2008) Assessing coastal vulnerability to climate change: comparing segmentation at global and regional scales. Sustain Sci 3:45-65

Torresan S, Gallina V, Giannini V, Rizzi J, Zabeo A, Critto A, Marcomini A (2012) DESYCO: a decision support system to provide climate services for coastal stakeholders dealing with climate change impacts Sea 8:10

Vincent K (2004) Creating an index of social vulnerability to climate change for Africa Tyndall Center for Climate Change Research Working Paper 56:41

Weisse R, von Storch H, Niemeyer HD, Knaack H (2012) Changing North Sea storm surge climate: an increasing hazard. Ocean Coast Manag 68:58-68

Welsh Government (2014) Written statement-coastal flooding-January 2014. http://gov.wales/about/ cabinet/cabinetstatements/2014/coastalflooding/?lang=en. Accessed 12 Apr 2015

White I, Howe J (2002) Flooding and the role of planning in England and Wales: a critical review. J Environ Plan Manag 45:735-745

Wolters ML, Kuenzer C (2015) Vulnerability assessments of coastal river deltas-categorization and review. J Coast Conservat 19:345-368

Woodworth P, Flather R, Williams J, Wakelin S, Jevrejeva S (2007) The dependence of UK extreme sea levels and storm surges on the North Atlantic Oscillation. Cont Shelf Res 27:935-946

Wu T, Hou X, Chen Q (2016) Coastal economic vulnerability to sea level rise of Bohai Rim in China. Nat Hazards 80:1231-1241

Yin J, Yin Z, Wang J, Xu S (2012) National assessment of coastal vulnerability to sea-level rise for the Chinese coast. J Coast Conserv 16:123-133

Zanuttigh B et al (2014) The Seus decision support system for coastal risk management. Coast Eng $87: 218-239$

Zsamboky M, Fernández-Bilbao A, Smith D, Knight J, Allan J (2011) Impacts of climate change on disadvantaged UK coastal communities York. Joseph Rowntree Found, UK 